\title{
Roles of Sorbitol and Sucrose in Growth and Respiration of 'Encore' Peaches at the Three Developmental Stages
}

\author{
Riccardo Lo Bianco and Mark Rieger \\ Department of Horticulture, University of Georgia, Athens, GA 30602
}

AdDITIONAL INDEX WORDS. acid invertase, Prunus persica, sink strength, sorbitol dehydrogenase, sorbitol oxidase, sucrose synthase

\begin{abstract}
In peach [Prunus persica (L.) Batsch (Peach Group)], both sorbitol and sucrose are used for source to sink carbon (C) transport, yet their specific functions in fruit growth and development remain unclear. Growth rate (GR), respiration rate $(R)$, carbohydrate content, and the activities of sorbitol dehydrogenase (SDH), sorbitol oxidase (SOX), sucrose synthase (SS), acid invertase (AI), and neutral invertase (NI) were determined in 'Encore' peaches to study the specific functions of sorbitol and sucrose in each phase of fruit development (an early period of rapid cell division, a relatively inactive intermediate stage where endocarp (pit) hardening occurs, and a final swelling due to cell expansion). Fruit growth and respiration rates ( $\mathrm{mol} \mathrm{C}$ /fruit per day) were always positively correlated, but the growth coefficient ( $\mathrm{g}_{\mathrm{c}}$ ) relating them was significantly higher at cell division, when maintenance respiration $\left(R_{m}\right)$ was nearly absent. Sorbitol and sucrose appeared to participate equally in growth and maintenance respiration. Contents of sorbitol and sucrose both correlated positively to GR, and their rates of accumulation increased from early to late growth stages in similar fashion. SDH activity was always positively correlated with sink strength and GR, but with $R$ only at endocarp hardening $(r=$ 0.632). SOX activity was also correlated with sink strength and GR in the early $(r=0.514$ and 0.553$)$ and late $(r=0.503$ and 0.495) growth phases, but not at endocarp hardening, and was correlated with $R$ in two of three growth phases. Among sucrose cleavage enzymes, AI activity was positively correlated with sink strength, GR, and R more strongly than the others $(r=0.51$ to 0.80$)$, but only in the cell division and cell expansion periods. SS activity was correlated with sink strength and $R$ only at endocarp hardening, and NI activity was generally not correlated to sink strength, GR, or R. We conclude that sorbitol and sucrose play similar roles in fruit development, and the enzymes associated with their metabolism work in concert to produce the observed changes in growth and respiration.
\end{abstract}

The peach [Prunus persica (Peach Group)] fruit, a drupe, undergoes three major growth phases during its development: an early period of rapid cell division, a relatively inactive intermediate stage where endocarp (pit) hardening and seed filling occur, and a final swelling due to cell expansion (Chalmers and Van den Ende, 1975). The overall growth pattern results in the doublesigmoid curve, typical of stone fruit. Fruit growth may be restricted by assimilate availability due to insufficient supply (supply limitation), deficiency in the capacity to deliver assimilates (transport limitation), or competition from other sinks (competition limitation); or by the organs' ability to utilize assimilates (sink limitation) (Wareing and Patrick, 1976). In peach trees with moderate to high fruit load, transport/competition limitations are observed in the early stages of fruit growth, sink limitations mainly during the midperiod, and a supply limitation during all phases, particularly during final swell(DeJong and Grossman, 1995; Pavel and DeJong, 1993).

Peaches are fairly unique among plants in that the source of carbon $(\mathrm{C})$ used in growth and translocation to both vegetative and reproductive sinks is predominantly sorbitol, not sucrose (Bieleski, 1982; Lo Bianco et al., 1999a). Sorbitol to sucrose ratios as high as $4: 1$ have been reported for mature peach leaves (Escobar-Gutierrez and Gaudillère, 1994), but decrease to 2:1 in leaf petioles, 2-year-old stem bark, and fruit peduncles (Lo Bianco, unpublished data). In the fruit, sorbitol and sucrose contents change during development and with the type of tissues within the organ (Lo Bianco, unpublished data; Lo Bianco et al., 1999a). Ratios of up to 1:4 and 1:50 (sorbitol to sucrose) are observed late in the season in the mesocarp (flesh) and seed, respectively (Lo Bianco, unpublished data). These differences in sorbitol to sucrose ratios of various tissues within the fruit, and the

Received for publication 12 Jan. 2001. Accepted for publication 20 Nov. 2001. fact that sucrose seems to accumulate more than sorbitol in the mesocarp during the season (Lo Bianco et al., 1999a), suggest that the two forms of translocated $\mathrm{C}$ may play different roles depending on the tissue and/or developmental stage.

A realistic estimate of sink strength is given by the sum of the organ's total C or dry weight (DW) gain measured during growth, plus its C loss due to respiration (Ho, 1988). Also, the net sink strength is the product of sink size, representing the physical constraint, and sink activity, reflecting the physiological constraint on assimilate import (Grossman and DeJong, 1994; Ho, 1988; Warren Wilson, 1972). General models for estimating respiration rate $(\mathrm{R})$ at the organ level indicate the presence of two major components: growth respiration $\left(\mathrm{R}_{\mathrm{g}}\right)$ and maintenance respiration $\left(R_{m}\right)$ (Amthor, 1994), according to the equation $R=R_{g}$ $+R_{m}$. The growth component of respiration is directly related to all catabolic processes that lead to the production of energy and $\mathrm{C}$ intermediates used in the construction of $\mathrm{C}$ skeletons and longterm storage. In the above equation, $\mathrm{R}_{\mathrm{g}}$ is given by the product of GR and $g_{c}$, where $g_{c}$ indicates the efficiency of respiration (unit increase in growth per unit increase in respiration). $R_{m}$, on the other hand, is related to the production of energy and intermediates used to maintain cell structure, in processes such as protein turnover, and repair after physical damage (pests and pathogens) or severe stress. $\mathrm{R}_{\mathrm{m}}$ is given by the $\mathrm{Y}$-axis intercept when $\mathrm{R}$ is plotted against GR (Amthor, 1994).

In plants where sucrose is the main form of translocated $C$, the activity of sucrose cleavage enzymes has been used successfully as an indicator of sink strength (Sung et al. 1989). However, in plants translocating sorbitol and sucrose, sorbitol dehydrogenase (SDH) is generally considered the predominant enzyme of sorbitol catabolism (Loescher et al., 1982; Yamaguchi et al., 1996; Yamaki and Ishikawa, 1986), and seems to play a more direct role than sucrose enzymes in the growth of vegetative sinks (Lo Bianco 
et al., 1999a, 1999b). In peach fruit mesocarp, however, activities of sorbitol oxidase (SOX) or SDH alone do not seem to explain all of the in vivo oxidation of sorbitol, or follow the fruit growth pattern (Lo Bianco et al., 1999a; Moriguchi et al., 1990). Among the enzymes of sucrose breakdown, acid invertase (AI) in the mesocarp follows closely the growth pattern of peaches (Lo Bianco et al., 1999a). Toward maturity, a decrease in the activities of all enzymes related to sucrose cleavage seems to explain accumulation of sucrose in the fruit mesocarp, rather than an increase of its synthesis (Lo Bianco et al., 1999a; Vizzotto et al., 1996). Also, an increase in sucrose phosphate synthase (SPS) and sucrose synthase (SS) activity assayed in the synthetic direction (Hubbard et al., 1991) or only SS activity (Moriguchi et al., 1990) may be associated to sucrose accumulation in peaches.

The objectives of this study were to first obtain an estimate of sink strength in each phase of fruit development by measuring growth and respiration rates. Secondly, we determined whether the growth, respiration, and maintenance processes were different in the three developmental stages. Finally, we hypothesized that each set of enzymes (or single enzyme) of sorbitol and/or sucrose catabolism would be associated with either growth, respiration, or sink strength in each phase of development, and this would indicate the roles that sorbitol and sucrose play in peach fruit growth.

\section{Materials and Methods}

Plant materials. Fruit were collected between April and July 2001 from 8-year-old 'Encore' peach trees located at the horticulture research farm near Athens, Ga. Trees were propagated on 'Lovell' rootstock, spaced $2 \times 7 \mathrm{~m}$ apart, and trained to a perpendicular $\mathrm{V}$ form. The soil type was a Cecil sandy clay loam (fine, kaolinitic, thermic Typic Kanhapludults). About $21 \mathrm{~d}$ after full bloom, one half of each tree, at alternating sides of the $\mathrm{V}$, was thinned heavily, leaving one fruit per shoot; the other half was left nonthinned. The thinning treatment had the sole purpose of increasing variation in fruit growth rates. Sampling for respiration and destructive measurements was repeated six times, twice in each of three phases of growth $(\approx 34$ and 46, 81 and 94, and 122 and $138 \mathrm{~d}$ after bloom), and it was not the scope of this study to describe the continuous seasonal change of the parameters measured. Samples were harvested early in the morning and transported from the field to the laboratory in plastic bags. Two separate sets of samples were collected, one used for determination of respiration and enzyme activities, and the second for later determination of carbohydrate content.

In peaches, as in other stone fruit, after a period of rapid cell division and tissue differentiation, a seed develops inside the endocarp as it undergoes hardening and lignification. The seed continues to develop during the phase of cell expansion in the mesocarp. Due to this physical delimitation and tissue differentiation, the seed can be considered as a separate organ with its own metabolism, growth, and respiration. However, nondestructive measurements only allow estimates of whole fruit growth and respiration. For this reason and for the fact that sink size constitutes a major component of sink strength (Warren Wilson 1972), we expressed our growth, respiration, sugar content, enzyme, and protein data on a per fruit basis rather than on a per unit weight basis. This approach was used to give an appropriate indication of sink strength of the entire fruit (mesocarp, endocarp, and seed), and its relationship with physiological and biochemical parameters that take into account both sink activity and size.

GROWTH, RESPIRATION, AND SINK STRENGTH. Three to $5 \mathrm{~d}$ before each sampling date, 30 fruit, evenly distributed in 15 trees (one fruit per side of the V-shaped tree), were tagged and their initial suture diameter was measured with a digital caliper to the nearest $0.1 \mathrm{~mm}$. The diameter was measured again on each sampling date, daily growth rate (GR) in millimeters per fruit was calculated, and eight fruit representing the entire growth range observed were sampled for determination of $\mathrm{R}$ and enzyme activities. Another eight fruit were selected using the same criterion and used for carbohydrate determination. Finally, 30 fruit were collected from the same trees on each sampling date to establish a correlation between diameter and DW. The fruit were measured for their suture diameter and then dried to constant weight at $70^{\circ} \mathrm{C}$. A linear regression between diameter and DW was obtained for each sampling date and used to estimate the DW of the samples used for respiration and enzyme assays. The DW in grams was then converted into grams of C by using the coefficient 0.475 reported by Grossman and DeJong (1994) for peaches. Growth rate was expressed in mol $\mathrm{C} /$ fruit per day.

Once in the laboratory, fruit were allowed to acclimate to room temperature ( 22 to $24^{\circ} \mathrm{C}$ ), and then enclosed in airtight containers with volumes ranging from 15 to $380 \mathrm{~mL}$ and for 11 to $115 \mathrm{~min}$ depending on fruit size and respiration rate. The final $\mathrm{CO}_{2}$ concentration in the container headspace was always kept below $1 \%$ to minimize solubilization of $\mathrm{CO}_{2}$ into the fruit liquid phase (according toHenry's law) and otherfeedback processes that could cause significant underestimation of respiration rates. One milliliter of air at known $\mathrm{CO}_{2}$ concentration and $1 \mathrm{~mL}$ of air from the containerheadspace wereinjected into a Fisher-Hamilton 29 gas partitioner (Fisher Scientific, Pittsburgh, Pa.) using a 2-m $\times$ 7-mm aluminum column packed with $30 \%$ di-2ethylhexylsebacate on 60 to 80 mesh ChromosorbPat ambient temperature, a cell temperature of $70^{\circ} \mathrm{C}$, and helium as carrier gas at a rate of 30 $\mathrm{mL} \cdot \mathrm{min}^{-1}$, toobtainstandard and samplechromatograms, respectively. The height of the $\mathrm{CO}_{2}$ peak in sample chromatograms was related to that of standard chromatograms to determine $\mathrm{CO}_{2}$ evolved from fruit. Respiration rate was expressed in mol C/fruit per day. Growth coefficients and $R_{m}$ were obtained from the linear regression equation of GR vs. R for the three phases of fruit development, pooling together data from two sampling dates within a phase. An estimate of sink strength in mol C/fruit per day was obtained by adding GR and $\mathrm{R}$ for each fruit sampled.

ENZYME EXTRACTION AND ASSAYS. On the first two sampling dates (cell division phase), when the endocarp had shown no sign of lignification yet, enzymes were extracted from a section of the entire fruit (one half) representing all developing tissues in proportion. After endocarp lignification started (from the $3^{\text {rd }}$ sampling date on), enzymes were extracted separately only from the fruitmesocarp and seed, as the woody endocarp was not extractable. For all the enzymes, the tissue to buffer ratio in the extractions was kept constant at $\approx 1: 3(\mathrm{w} / \mathrm{v})$ for fruit mesocarp and $1: 6(\mathrm{w} / \mathrm{v})$ for the seeds. $\mathrm{SDH}, \mathrm{SS}, \mathrm{SOX}$, and the soluble fraction of AI and NI were extracted and assayed as described in Lo Bianco et al. (1999a) with few modifications. Briefly, SDH was extracted in $0.2 \mathrm{M}$ Tris-HCl buffer $\left(\mathrm{pH} 9\right.$ at $25{ }^{\circ} \mathrm{C}$ ) containing $8 \%$ (v/v) glycerol, and $20 \mathrm{~mm} 2-$ mercaptoethanol. SS, AI, NI, and SOX were extracted in $0.2 \mathrm{M}$ Hepes/NaOHbuffer ( $\mathrm{pH} 7.5$ at $25^{\circ} \mathrm{C}$ ) containing $10 \mathrm{~mm}$ dithiothreitol (DTT), 3 mm Mg-acetate, and 8\% (v/v) glycerol. Tween 20 (0.1\%, $\mathrm{v} / \mathrm{v}$ ) and polyvinylpolypyrrolidone (PVPP; $1 \%, \mathrm{w} / \mathrm{v}$ ) were added in all extractions during grinding. The homogenates were centrifuged at $3000 g_{\mathrm{n}}$ for $15 \mathrm{~min}$ and the supernatants desalted with Sephadex G-25 (medium) columns.

Sorbitol dehydrogenase was assayed by measuring the continuous change in optical density (OD) at $340 \mathrm{~nm}$ at $25^{\circ} \mathrm{C}$ on a Spectronic Genesys 5 spectrophotometer (Spectronic Instruments, 
Inc., Rochester, N.Y.) over a 5-min period using $0.2 \mathrm{~mL}$ of desalted extract, $0.1 \mathrm{~m}$ Tris- $\mathrm{HCl}$ buffer (pH 9.5 at $\left.25^{\circ} \mathrm{C}\right)$, and $1 \mathrm{~mm} \mathrm{NAD}$. The reaction was started by adding $400 \mathrm{~mm}$ sorbitol $(1 \mathrm{~mL}$ final volume). SS was assayed by measuring the continuous change in $\mathrm{OD}$ at $340 \mathrm{~nm}$ at $25^{\circ} \mathrm{C}$ on the Spectronic Genesys 5 using $0.2 \mathrm{~mL}$ of desalted extract, $100 \mathrm{~mm}$ sucrose, $0.5 \mathrm{~mm}$ UDP, and $1 \mathrm{~mm}$ PPi as substrates, and phosphoglucomutase (1 unit) and leuconostoc glucose-6-phosphate dehydrogenase (1 unit) as coupling enzymes. AI and NI were assayed with $25 \mathrm{~mm}$ sucrose at $\mathrm{pH} 5$ and $100 \mathrm{~mm}$ sucrose at $\mathrm{pH} 7$, respectively, whereas SOX was assayed with $400 \mathrm{~mm}$ sorbitol at $\mathrm{pH} 4$. After $30 \mathrm{~min}$ of incubation at $25^{\circ} \mathrm{C}$, the reaction was stopped by boiling for $10 \mathrm{~min}$. The AI and SOX reaction mixtures were neutralized before boiling. The glucose formed was measured using hexokinase (1 unit) and leuconostoc glucose-6-phosphate dehydrogenase (1 unit). In all enzyme assays, activities were proportional to the amount of extract and time.

Total fruit enzyme activity was calculated by adding the total activity in each tissue when extracted separately, and was expressed as nmol of $\mathrm{NADH} /$ min per fruit. Protein content was determined by the method of Bradford (1976) and expressed as milligrams per fruit.

SORBITOL AND NONSTRUCTURAL CARBOHYDRATES. About 0.1 to $0.12 \mathrm{~g}$ of mesocarp or seed tissue were ground in a mortar and pestle with $2 \mathrm{~mL}$ of $80 \%$ (v/v) methanol containing $0.22 \mathrm{mg}$ of phenyl- $\beta$ D-glucopyranose as an internal standard. After homogenization, samples were centrifuged for $10 \mathrm{~min}$ at $2000 \mathrm{~g}_{\mathrm{n}}$ and $1 \mathrm{~mL}$ of the supernatant was stored at $4{ }^{\circ} \mathrm{C}$ for soluble carbohydrate and sorbitol determination. The pellet was washed with $80 \%$ methanol and centrifuged twice. The supernatant was discarded, $1 \mathrm{~mL}$ of deionized water was added, and tubes were placed in a water bath at 100 ${ }^{\circ} \mathrm{C}$ for $1 \mathrm{~h}$ to gelatinize the starch. One milliliter of deionized water, $1 \mathrm{~mL}$ of acetate buffer ( $\mathrm{pH} 4.8$ ), and $0.1 \mathrm{~mL}$ of amyloglucosidase enzyme solution ( 7 units) were added and tubes were placed in a water bath at $55^{\circ} \mathrm{C}$ for $24 \mathrm{~h}$. Tubes were then centrifuged for $10 \mathrm{~min}$ at $2000 g_{\mathrm{n}}$ and $1 \mathrm{~mL}$ of the supernatant was stored at $-20^{\circ} \mathrm{C}$ for starch determination. Samples were prepared and sugars were quantified by gas chromatography as described by Lo Bianco et al. (2000).

Starch content was determined by measuring enzymatically the amount of glucose formed (modified from Chaplin, 1994). Hexokinase (1 unit) and leuconostoc glucose-6-phosphate dehydrogenase (1 unit) were used in the presence of ATP and NAD and the total change in OD was measured spectrophotometrically. As for GR, R, sink strength, proteincontent, andenzyme activities, total carbohydrate content was calculated by adding the total content in each tissue and was expressed on a per organ basis (grams per fruit) to better reflect the condition of the entire sink.

Statistical analysis. Sigma Stat procedures (SPSS, Inc., Chicago, Ill.) were used to determine simple correlation coefficients, linear regressions, and differences among means of treatments. Differences among slopes and among intercepts of regression lines were tested by performing an analysis of variance with the coefficients, SE values, and sample size from the regression output. For SDH, SS, and NI activities, analysis of variance and mean separation could not be performed due to lack of homogeneity in the variance of original and transformed data. In cases in which homogeneity of variance was satisfied,
Tukey's studentized range test was used to separate means among fruit growth phases. Linear regressions presented in figures are significant at $P \leq 0.05$.

\section{Results}

FrUIT GROWTH, SINK STRENGTH, AND RESPIRATION. As expected, fruit on the thinned side of trees were significantly larger than nonthinned fruit at all sampling dates (data not presented). Thus, thinning accentuated differences in fruit growth over the season, although the fastest growing fruit at any given sampling point were not always those on the thinned side of trees. Fruit diameter and DW were always significantly correlated (data not presented). GR was linearly related to $\mathrm{R}$ in all three phases of fruit growth (Fig. 1). On average, R accounted for $27 \%, 35 \%$, and $14 \%$ of sink strength at cell division, endocarp hardening, and cell expansion, respectively. The growth coefficient (slope of regression lines in Fig. 1) at the cell division stage was significantly greater than that at the endocarp hardening and cell expansion phases (Table 1). Conversely, $R_{m}$ was nearly absent at cell division and increased at endocarp hardening and cell expansion. Total protein content per fruit increased significantly from early to late fruit growth stages (Table 1).

SORBITOL AND NONSTRUCTURAL CARBOHYDRATES. Sorbitol and sucrose contents were linearly related to GR in each growth stage (Fig. 2), and their contribution to fruit growth increased from cell division to cell expansion in a similar fashion (Table 1). Starch content was positively correlated with GR in the first two phases of fruit development, but showed an inverse relationship at cell expansion (Fig. 3).

ENZYME ACTIVITIES. Enzyme activities within each phase of fruit development varied greatly and not in a homogeneous fashion (Table 2) due in part to nonrandom sampling (fruit were sampled to

Fig. 1. Linear regression plots of growth rate $(\mathrm{GR})$ vs. respiration rate $(\mathrm{R})$ in the three phases of 'Encore' peach fruit development $(P \leq 0.05)$. Each regression line is based on 16 observations. At cell division $\mathrm{R}=0.322 \times$ $\mathrm{GR}+0.0001$; at endocarp hardening $\mathrm{R}=0.088 \times \mathrm{GR}+0.002$; at cell expansion $\mathrm{R}=0.037 \times \mathrm{GR}+0.0018$.

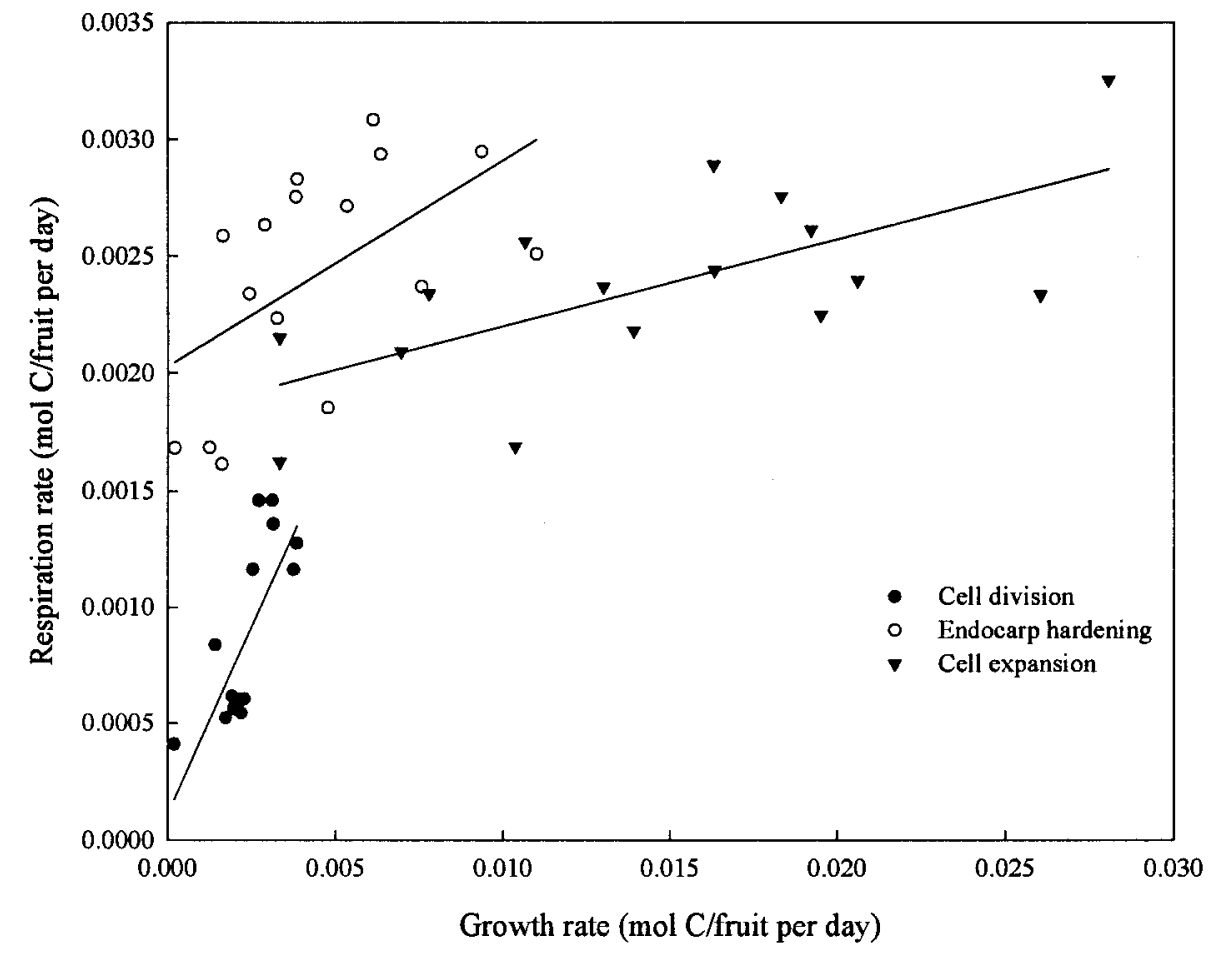


Table 1. Growth coefficients $\left(\mathrm{g}_{\mathrm{c}}\right)$, maintenance respiration $\left(\mathrm{R}_{\mathrm{m}}\right)$, protein content, and slopes of regression lines of growth rate (GR; mol C/fruit per day) vs. sorbitol content (g/fruit) and GR vs. sucrose content in the three phases of 'Encore' peach fruit development.

\begin{tabular}{|c|c|c|c|c|c|}
\hline $\begin{array}{l}\text { Growth } \\
\text { phase }\end{array}$ & $\begin{array}{c}\mathrm{g}_{\mathrm{c}} \\
(\mathrm{mol} \mathrm{C} / \mathrm{mol} \mathrm{C})\end{array}$ & $\begin{array}{c}\mathrm{R}_{\mathrm{m}} \\
(\mathrm{mol} \mathrm{C} / \text { fruit per day) }\end{array}$ & $\begin{array}{l}\text { Protein } \\
\text { (mg/fruit) }\end{array}$ & $\begin{array}{l}\text { GR vs. } \\
\text { sorbitol }\end{array}$ & $\begin{array}{l}\text { GR vs. } \\
\text { sucrose }\end{array}$ \\
\hline Cell division & $0.322 \mathrm{a}^{\mathrm{z}}$ & $0.00011 \mathrm{~b}$ & $53.9 \mathrm{c}$ & $13.7 \mathrm{~b}$ & $11.4 \mathrm{~b}$ \\
\hline Endocarp hardening & $0.088 \mathrm{~b}$ & $0.00203 \mathrm{a}$ & $160.0 \mathrm{~b}$ & $41.0 \mathrm{ab}$ & $75.0 \mathrm{ab}$ \\
\hline Cell expansion & $0.037 \mathrm{~b}$ & $0.00183 \mathrm{a}$ & $395.5 \mathrm{a}$ & $69.2 \mathrm{a}$ & $180.4 \mathrm{a}$ \\
\hline
\end{tabular}

${ }^{\mathrm{z}}$ Mean separation $(\mathrm{n}=16)$ within columns by Tukey's studentized range test, $P \leq 0.05$.

cover the widest GR range possible). For this reason, a comparison among growth phases could not be performed for some enzyme activities. Only AI activity decreased significantly $(P=0.05)$ at the final stage. However, a characterization of seasonal changes in enzyme activities was not the purpose of this study and has been reported in a previous work (Lo Bianco et al., 1999a).

The activity of SDH was the only one to correlate positively with sink strength and GR in each phase of fruit growth (Table 3). However, SDH activity was correlated with R only at endocarp hardening. SOX activity was correlated to sink strength and GR only in the cell division and cell expansion phases, whereas correlations with $\mathrm{R}$ were significant only at endocarp hardening and cell expansion. Activity of AI was correlated with sink strength, GR, and R in the initial and final stages of fruit development. On the other hand, SS activity was associated with sink strength and R only at endocarp hardening. NI activity was never correlated with sink strength or GR, and with R only at cell division.

\section{Discussion}

Differences in GR, R, and carbohydrate content and metabolism were observed in the three different phases of fruit development, as expected. At all stages, GR correlated with R. However, the higher $g_{c}$ in the early phase of fruit development (Table 1) suggests that early processes, including cell division, use a good deal of energy and $C$ intermediates per unit of weight increase, lowering the efficiency of respiration. In the same period, the low $\mathrm{R}_{\mathrm{m}}$ indicates that peaches use little or no $\mathrm{C}$ for tissue maintenance and/ or repair. Under optimal growth conditions, this may be due primarily to the relatively small size of the fruit at this stage, since $R_{m}$ is equal to the product of a maintenance coefficient and the organ's mass (Amthor, 1994). The increase in $R_{m}$ in mid and late stages of fruit development could, in part, be explained by the increase in total protein content (due to mainly a remarkable accumulation in the seed) because protein turnover is considered the maintenance process using the largest amount of respiratory products (Penning de Vries, 1975). The higher contribution of sorbitol and sucrose to fruit growth in the late stages of fruit growth (Table 1, Fig. 2) may also explain, alone or in part, the

Fig. 2. Linear regression plots of (A) growth rate (GR) vs. sorbitol content and (B) GR vs. sucrose content in the three phases of 'Encore' peach fruit development $(P \leq 0.05)$. Each regression line is based on 16 observations. Note different $\mathrm{Y}$-axis scales in (A) and (B). At cell division sorbitol $=13.7 \times \mathrm{GR}-0.003$ and sucrose $=11.4 \times \mathrm{GR}-$ 0.007 ; at endocarp hardening sorbitol $=41.0 \times \mathrm{GR}+0.067$ and sucrose $=75.0 \times \mathrm{GR}+0.429$; at cell expansion sorbitol $=69.2 \times \mathrm{GR}+0.677$ and sucrose $=180.4 \times \mathrm{GR}+2.24$. increase in respiration efficiency or decrease in $g_{c}$ observed in these phases. About $40 \%$ of the final fruit DW is in fact constituted by sorbitol and sucrose that, if symplastic unloading is assumed, enter and accumulate in the fruit at nearly no respiratory cost. Even if an apoplastic step is involved in the unloading of sucrose and de novo synthesis is needed for sucrose to accumulate, respiratory costs would remain lower than those required for synthesis of proteins and other structural compounds. Furthermore, cell expansion is driven by turgor pressure, and sorbitol and sucrose would represent the major osmolytes used to generate turgor. The lower accumulation of sorbitol as compared to that of sucrose could be due in part to the

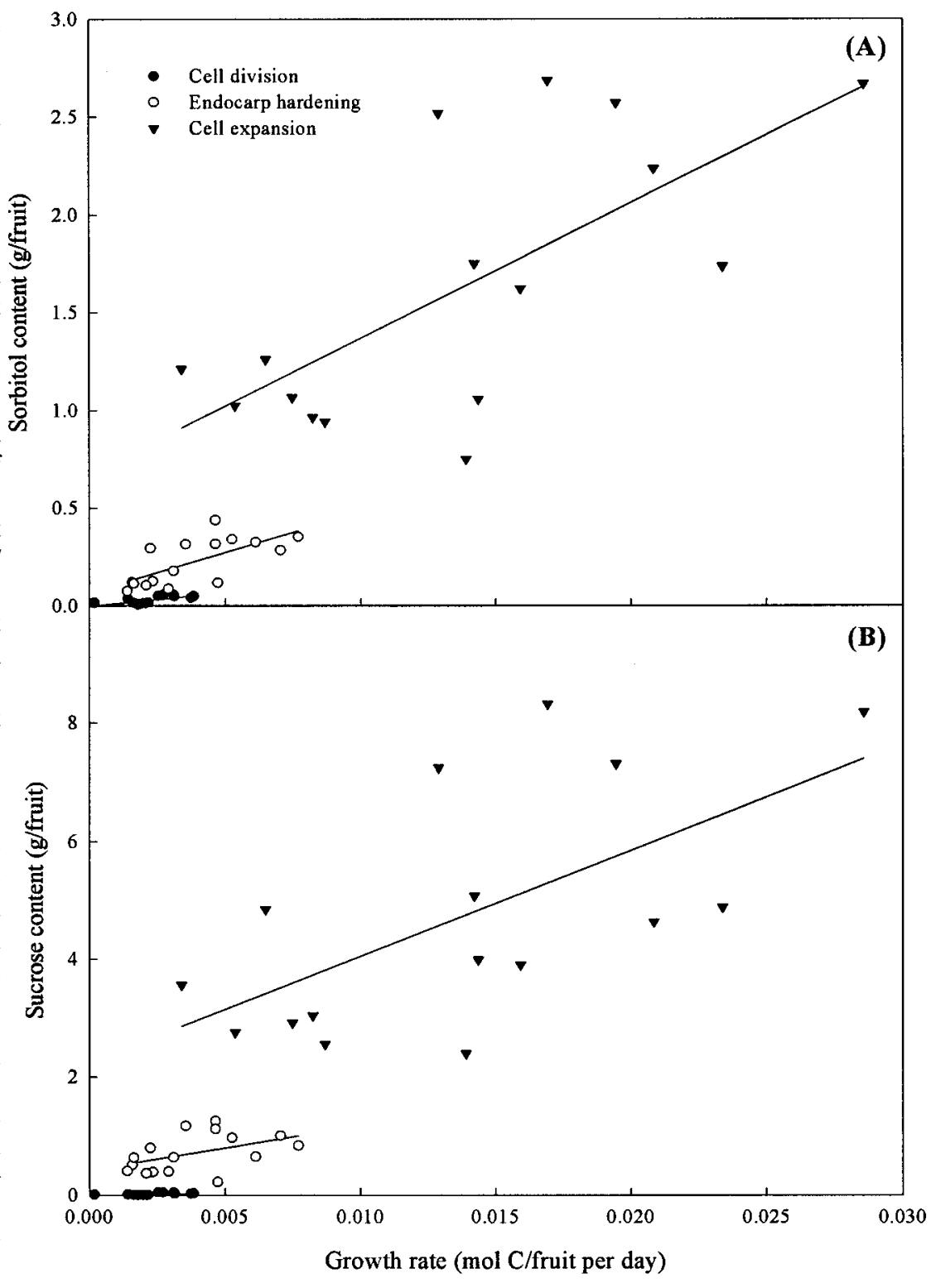




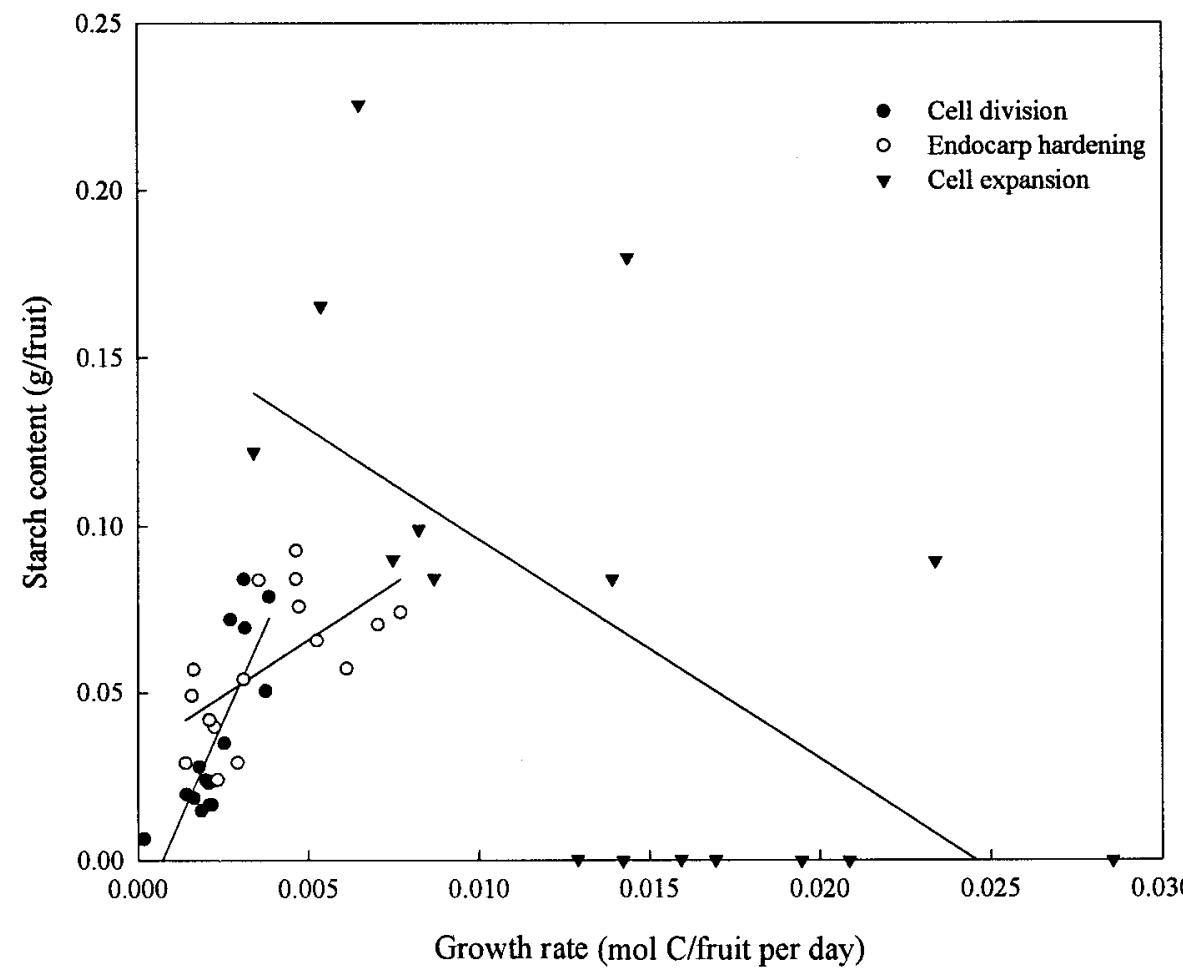

Fig. 3. Linear regression plots of growth rate (GR) vs. starch content in the three phases of 'Encore' peach fruit development $(P \leq 0.05)$. Each regression line is based on 16 observations. At cell division starch $=23.1 \times \mathrm{GR}-0.017$; at endocarp hardening starch $=6.72 \times \mathrm{GR}+0.032$; at cell expansion starch $=-6.58 \times \mathrm{GR}+0.162$.

efficiency. However, sucrose cleavage at the sink does not produce NADH.

Growth accounted for about $65 \%$ to $86 \%$ of sink strength during fruit development, with respiration accounting for the balance. Thus, it is not surprising that the enzymes correlated with GR are also generally correlated with sink strength. The relative contribution of $R$ to total sink strength was highest at endocarp hardening. At the beginning of endocarp hardening, the seed has already nearly reached its final fresh weight (data not presented). However, the seed DW continues to increase until the end of fruit development due to major changes in tissue composition. Mainly, the watery seed tissue is gradually replaced by storage proteins and lipids, the synthesis of which involves high respiratory costs compared to that of carbohydrate accumulation fact that about half of the weight of the 6-C sorbitol is needed to generate an osmotic potential equal to that generated by the 12-C sucrose. Thus, with respect to their function as osmolytes, sorbitol ties up less $\mathrm{C}$ per unit of osmotic potential decrease than an equimolar concentration of sucrose. Furthermore, oxidation of sorbitol catalyzed by SDH at the sink yields a net production of $\mathrm{NADH}$, which may partly contribute to the increase in respiration

(Amthor, 1994). This relatively high demand of energy per unit weight increase may be responsible for a decrease in respiration efficiency in the seed and for the observed increase in R as a percentage of sink strength at endocarp hardening.

For the reasons mentioned above, the fact that SDH activity always correlates with GR and sink strength, but with R only at endocarp hardening (Table 3), suggests that its activity may be

Table 2. Activity (mean \pm SE) of sorbitol and sucrose enzymes in the three phases of 'Encore' peach fruit development. Data presented in this table have the sole purpose of giving an indication of the average enzyme activities detected in the three fruit growth phases.

\begin{tabular}{lcccc}
\hline \hline Growth & SDH & SOX & SS & AI \\
\cline { 2 - 5 } phase & \multicolumn{3}{c}{ NI } \\
\hline Cell division & $151 \pm 15^{z}$ & $155 \pm 15$ & $687 \pm 67$ & $675 \pm 45$ \\
Endocarp hardening & $220 \pm 42$ & $13 \pm 4$ & $421 \pm 84$ & $455 \pm 46$ \\
Cell expansion & $413 \pm 81$ & $796 \pm 348$ & $1348 \pm 296$ & $298 \pm 140$
\end{tabular}

${ }^{\bar{z}} \mathrm{~A}$ complete statistical analysis to assess differences among growth phases is not presented as homogeneity of variance was not satisfied in either original or transformed data for some enzymes.

Table 3. Coefficients of correlation between growth rate (GR, mol C/fruit per day), respiration rate (R, mol C/fruit per day), and sink strength (GR $+\mathrm{R}$ ) vs. enzyme activities (nmol· $\mathrm{min}^{-1}$ per fruit) in the three phases of 'Encore' peach fruit development.

\begin{tabular}{|c|c|c|c|c|c|}
\hline Growth phase & $\mathrm{SDH}$ & SOX & SS & $\mathrm{AI}$ & $\mathrm{NI}$ \\
\hline \multicolumn{6}{|l|}{ Cell division } \\
\hline GR & $0.644^{* *}$ & $0.553^{*}$ & $0.053^{\mathrm{NS}}$ & $0.761^{* *}$ & $0.290^{\mathrm{NS}}$ \\
\hline $\mathrm{R}$ & $0.446^{\mathrm{NS}}$ & $0.333^{\mathrm{NS}}$ & $0.435^{\mathrm{NS}}$ & $0.762^{* *}$ & $0.788^{* * *}$ \\
\hline $\mathrm{GR}+\mathrm{R}$ & $0.617^{* *}$ & $0.514^{*}$ & $0.098^{\mathrm{NS}}$ & $0.804^{* *}$ & $0.463^{\mathrm{Ns}}$ \\
\hline \multicolumn{6}{|c|}{ Endocarp hardening } \\
\hline GR & $0.515^{*}$ & $0.017^{\mathrm{NS}}$ & $0.477^{\mathrm{NS}}$ & $0.125^{\mathrm{NS}}$ & $0.298^{\mathrm{NS}}$ \\
\hline $\mathrm{R}$ & $0.632^{* *}$ & $0.516^{*}$ & $0.495^{*}$ & $0.375^{\mathrm{Ns}}$ & $0.073^{\mathrm{NS}}$ \\
\hline $\mathrm{GR}+\mathrm{R}$ & $0.563^{*}$ & $0.091^{\mathrm{Ns}}$ & $0.508^{*}$ & $0.169^{\mathrm{Ns}}$ & $0.282^{\mathrm{Ns}}$ \\
\hline \multicolumn{6}{|l|}{ Cell expansion } \\
\hline GR & $0.549^{*}$ & $0.495^{*}$ & $0.371^{\mathrm{NS}}$ & $0.666^{* *}$ & $0.225^{\mathrm{Ns}}$ \\
\hline $\mathrm{R}$ & $0.308^{\mathrm{NS}}$ & $0.499^{*}$ & $0.216^{\mathrm{NS}}$ & $0.514^{*}$ & $0.120^{\mathrm{NS}}$ \\
\hline $\mathrm{GR}+\mathrm{R}$ & $0.546^{*}$ & $0.503^{*}$ & $0.369^{\mathrm{NS}}$ & $0.669^{* *}$ & $0.223^{\mathrm{NS}}$ \\
\hline
\end{tabular}

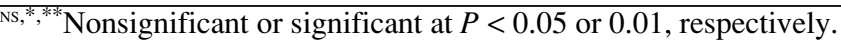


associated to seed development at this stage. In other words, SDH activity always correlated with fruit growth, but with $\mathrm{R}$ only at endocarp hardening, when the contribution of $\mathrm{R}$ to fruit sink strength increases due to seed compositional changes. SS behaves similarly in the same period and seems to be associated only with seed development. SOX is associated with GR and sink strength at cell division (Table 3 ), when it is predominantly active in the endocarp. Later in the mid and late phases, SOX is most active in the seed (data not presented) and correlates with $\mathrm{R}$ (Table 3) perhaps for the same reasons as for SDH. AI, on the other hand, was associated with all three parameters, sink strength, GR, and R, only at cell division and cell expansion (Table 3 ). The behavior of AI is probably rather complex, and may be associated to processes occurring mainly in the fruit mesocarp, such as growth and respiration in the early phase, and sucrose accumulation in the final stage. The latter is supported by the fact that AI activity nearly disappears in the mesocarp at final swell (data not presented). Similar results were obtained in previous studies with 'Encore' (Lo Bianco et al., 1999a) and 'Redhaven' peaches (Vizzotto et al., 1996). The role of NI in peach growth is not clear because its activity generally did not correlate with GR, R, or sink strength. Its involvement in maintenance and/or repair processes may only be hypothesized (Black et al., 1987).

The positive correlation between starch content and GR in the early and mid stages of fruit development suggests that starch is synthesized when the supply of assimilates is generally high or even exceeds the demand for growth and respiration. Late in the season, the inverse relationship between GR and starch content implies that starch may be used as an additional source of $\mathrm{C}$ and the ability to break it down may be involved in regulation of growth rates and carbohydrate accumulation. Under sourcelimiting conditions, starch becomes an alternative $\mathrm{C}$ source for growth and de novo synthesis of sucrose in apple [Malus sylvestris (L.) Mill. var. domestica (Borkh.) Mansf.] fruit (Berüter and Studer-Feusi, 1997).

The relatively high enzyme activities found in the seed at endocarp hardening and cell expansion explain some of the differences between the results obtained in the present study and those from previous research (Lo Bianco et al., 1999a), in which sorbitol and sucrose metabolic enzymes were extracted from the fruit mesocarp only. Specifically, when the entire fruit sink is assayed, the activity of the sorbitol metabolizing enzyme SDH represents a slightly better indicator of sink strength than the activities of the sucrose metabolizing enzymes in all three phases of fruit development.

In conclusion, the three phases of peach development were characterized by different rates and type of growth (cell division, cell expansion, and changes in tissue sugar, protein, and lipid content), as well as rates, type (growth vs. maintenance), and efficiency of respiration. These differences were often accompanied by differences in sorbitol and sucrose accumulation, and activities of the enzymes involved in their catabolism. Sorbitol and sucrose show similar behavior during peach development, and no unique role for sorbitol as compared to sucrose has emerged in the present study. The observed rates of growth, respiration, and carbohydrate accumulation are therefore the result of the concerted activity of all enzymes of sorbitol and sucrose metabolism in peaches.

\section{Literature Cited}

Amthor, J.S. 1994. Respiration and carbon assimilate use, p. 221-250. In: K.J. Boote, T.R. Sinclair, and J.M. Bennett (eds.). Physiology and determination of crop yield. Amer. Soc. Agron. Madison, Wis.

Berüter J. and M.E. Studer-Feusi. 1997. The effect of girdling on carbohydrate partitioning in the growing apple fruit. J. Plant Physiol. 151:277-285.

Bieleski, R. L. 1982. Sugar alcohols, p. 158-192. In: F.A. Loewus and W. Tanner (eds.). Plant carbohydrates I. Intracellular carbohydrates. vol. 13A. Encycl. Plant Physiol. (New Ser.). Springer-Verlag, Berlin

Black, C.C., L. Mustardy, S.S. Sung, P.P. Kormanik, D.P. Xu, and N. Paz. 1987. Regulation and roles for alternative pathways of hexose metabolism in plants. Physiol. Plant. 69:387-394.

Bradford, M.M. 1976. A rapid and sensitive method for the quantitation of microgram quantities of protein using the principle of protein-dye binding. Anal. Biochem. 72:248-254.

Chalmers, D.J. and B. Van den Ende. 1975. Productivity of peach trees: Factors affecting dry-weight distribution during tree growth. Ann. Bot. 39:423-432. Chaplin, M.F. 1994. Monosaccharides, p. 1-42. In: M.F. Chaplin and J.F. Kennedy (eds.). Carbohydrate analysis: A practical approach. Oxford Univ. Press, Oxford, United Kingdom.

DeJong, T.M. and Y.L. Grossman. 1995. Quantifying sink and source limitations on dry matter partitioning to fruit growth in peach trees. Physiol. Plant. 95:437-443.

Escobar-Gutierrez, A. J. and J.P. Gaudillère. 1994. Variability in sorbitol:sucrose ratios in mature leaves of different peach cultivars. J. Amer. Soc. Hort. Sci. 119:321-324.

Grossman, Y.L. and T.M. DeJong. 1994. PEACH: A simulation model of reproductive and vegetative growth in peach trees. Tree Physiol. 14:329-345.

Ho, L.C. 1988. Metabolism and compartmentation of imported sugars in sink organs in relation to sink strength. Annu. Rev. Plant Physiol. Plant Mol. Biol. 39:355-378.

Hubbard, N.L., D.M. Pharr, and S.C. Huber. 1991. Sucrose phosphate synthase and other sucrose metabolizing enzymes in fruits of various species. Physiol. Plant. 82:191-196.

Lo Bianco, R., M. Rieger, and S.S. Sung. 1999a. Carbohydrate metabolism of vegetative and reproductive sinks in the late-maturing peach cultivar 'Encore'. Tree Physiol. 19:103-109.

Lo Bianco, R., M. Rieger, and S.S. Sung. 1999b. Activities of sucrose and sorbitol metabolizing enzymes in vegetative sinks of peach and correlation with sink growth rate. J. Amer. Soc. Hort. Sci. 124:381-388.

Lo Bianco, R., M. Rieger, and S.S. Sung. 2000. Effect of drought on sorbitol and sucrose metabolism in sinks and sources of peach. Physiol. Plant. 108:71-78.

Loescher, W.H., G.C. Marlow, and R.A. Kennedy. 1982. Sorbitol metabolism and sink-source interconversions in developing apple leaves. Plant Physiol. 70:335-339.

Moriguchi, T., T. Sanada, and S. Yamaki. 1990. Seasonal fluctuations of some enzymes related to sucrose and sorbitol metabolism in peach fruit. J. Amer. Soc. Hort. Sci. 115:278-281.

Pavel, E.W. and T.M. DeJong. 1993. Source- and sink-limited growth periods of developing peach fruits indicated by relative growth rate analysis. J. Amer. Soc. Hort. Sci. 118:820-824.

Penning de Vries, F.W.T. 1975. The cost of maintenance processes in plants. Ann. Bot. 39:77-92.

Sung, S.S., D.P. Xu, and C.C. Black. 1989. Identification of actively filling sucrose sinks. Plant Physiol. 89:1117-1121.

Vizzotto, G., R. Pinton, Z. Varanini, and G. Costa. 1996. Sucrose accumulation in developing peach fruit. Physiol. Plant. 96:225-230.

Wareing, P.F. and J. Patrick. 1976. Source-sink relations and the partitioning of assimilates in the plant, p. 481-499. In: J. P. Cooper (ed.). Photosynthesis and productivity in different environments. Cambridge Univ. Press, Cambridge, United Kingdom.

Warren Wilson, J. 1972. Control of crop processes, p. 7-30. In: A.R. Rees, K.E. Cockshull, D.W. Hand, and R.G. Hurd (eds.). Crop processes in controlled environments. Academic Press, London.

Yamaguchi, H., Y. Kanayama, J. Soejima, and S. Yamaki. 1996. Changes in the amounts of the NAD-dependent sorbitol dehydrogenase and its involvement in the development of apple fruit. J. Amer. Soc. Hort. Sci. 121:848-852.

Yamaki, S. and K. Ishikawa. 1986. Roles of four sorbitol related enzymes and invertase in the seasonal alteration of sugar metabolism in apple tissue. J. Amer. Soc. Hort. Sci. 111:134-137. 